\title{
PERAN DAN KEDUDUKAN PETANI DALAM SISTEM PERDAGANGAN INTERNASIONAL
}

\author{
Moch Najib Imanullah, Emmy Latifah, Anugrah Adistuti \\ Fakultas Hukum Universitas Sebelas Maret \\ E-mail: imanullahnajib@yahoo.com, emmy.latifah \\ @yahoo.com,diaz.fhuns@yahoo.com
}

\begin{abstract}
This study aims to determine the role and position of farmer in the international trading system today. The development of the international trading system has an impact on the shift of food production system and food security policy which ultimately also has an impact on farmer's role and position in the global market. Evolution of agricultural structures in any periodization provide a clear description of the role and position of farmers in every era to enter the globalization. The globalization era was shaping a more liberal market system so that the role and position of farmers is becoming increasingly difficult in the international trading system.
\end{abstract}

Keywords: role, position, farmer, international trading system.

\begin{abstract}
Abstrak
Penelitian ini bertujuan untuk mengetahui peran dan kedudukan petani dalam sistem perdagangan internasional dewasa ini. Perkembangan sistem perdagangan internasional berdampak pada pergeseran sistem produksi pangan dan kebijakan ketahanan pangan yang akhirnya juga berdampak pada peran dan kedudukan petani di pasar global. Evolusi struktur pertanian dalam setiap periodesasi memberikan gambaran yang jelas mengenai peran dan kedudukan petani pada setiap masanya hingga memasuki era globalisasi. Era globalisasi membentuk sistem pasar yang lebih liberal sehingga peran dan kedudukan petani menjadi semakin sulit dalam sistem perdagangan internasional.
\end{abstract}

Kata kunci: peran, kedudukan, petani, sistem perdagangan internasional.

\section{A. Pendahuluan}

Walaupun selama ini petani memiliki peran yang signifikan dalam produksi pangan global, namun kedudukan hukum petani dalam sistem perdagangan internasional belum jelas (Wiggins, 2011). Ketidakjelasan ini mengakibatkan petani tetap saja miskin, tak berdaya, dan terpinggirkan. Petani merupakan penghasil sebagian besar bahan pangan di negara-negara berkembang (Koohafkan, 2011). Mereka menghasilkan 70 persen pasokan makanan di Afrika (IAASTD, 2009) dan 80 persen pasokan makanan di Asia dan Afrika secara bersama (IFAD, 2011). Di Amerika Latin, petani kecil menempati hampir 35 persen lahan pertanian (Altieri and Koohafkan, 2008). Bahkan, menurut penelitian yang dilakukan oleh International Funding for Agricultural Development (IFAD) bekerjasama dengan United Nations Environment Programme (UNEP), hingga tahun 2011, terdapat lebih dari 1,4 milyar orang hidup di bawah garis kemiskinan. Satu milyar dari mereka hidup di pedesaan dengan pekerjaan pokok sebagai petani (IFAD, 2013: 4). Data ini menunjukkan bahwa walaupun peran petani sangat penting, namun ternyata petani merupakan salah satu golongan masyarakat yang belum mendapatkan kehidupan yang layak.

Revolusi hijau di bidang pertanian yang dilakukan oleh sebagain besar negara berkembang pada kurun waktu 1960-1970 bertujuan untuk meningkatkan produktivitas pertanian secara dramatis dan pada akhirnya diharapkan dapat mengurangi kemiskinan. Namun demikian, revolusi hijau ternyata telah menyisakan banyak persoalan termasuk kerusakan lingkungan, degradasi lahan, menurunnya air tanah, hilangnya biodiversity dan lain sebagainya (Hazell, 2003). Selain itu, selama rentang waktu setengah abad sejak revolusi hijau hingga sekarang, berkurangnya investasi di bidang pertanian serta kenaikan harga input pertanian (benih, pupuk, irigasi) dan perubahan iklim telah memposisikan 
petani ke dalam posisi yang rentan dan sulit keluar dari lingkaran kemiskinan.

Kondisi yang dihadapi petani telah berubah. Petani menghadapi tantangan yang belum pernah terjadi sebelumnya. Secara global, perubahan yang signifikan di bidang politik, ekonomi, dan sosial budaya juga sangat mempengaruhi kondisi petani. Ditambah pula dengan pengaruh perubahan struktur pasar, kenaikan harga bahan bakar dan pupuk, perubahan iklim merupakan beberapa faktor yang mempengaruhi kondisi petani masa kini yang semakin sulit dan ini semua menimbulkan tantangan yang tidak mudah bagi para petani. Investasi di bidang pembangunan pertanian tidak lebih maju dari investasi di sektor lain. Petani seringkali diabaikan dalam perdebatan masa depan pertanian (Wiggins, 2011).

Artikel ini mengkaji bagaimana peran dan kedudukan petani dalam sistem perdagangan internasional.

\section{B. Metode Penelitian}

Penelitian ini adalah penelitian hukum normatif (doktrinal). Data yang digunakan dalam penelitian ini adalah data sekunder yang terdiri dari bahan hukum primer berupa peraturan perundangundangan dan bahan sekunder yang bersumber dari jurnal, penelitian terdahulu dan buku referensi yang relevan. Data diperoleh melalui studi pustaka dan dianalisis dengan menggunakan teknik content identification. Teknik validitas data menggunakan kritik sumber, selanjutnya dianalisis dengan edyting analysis style (Carbtree, 1995).

\section{Hasil Penelitian dan Pembahasan}

\section{Istilah dan Pengertian Petani}

Hingga kini, walaupun setiap pemangku kepentingan bahkan negara telah menetapkan istilah dan definisi mengenai petani, baik untuk tujuan analisis maupun tujuan pelaksanaan program pemerintah, namun sebenarnya belum ada satu definisi yang disepakati secara universal mengenai istilah dan pengertian petani. Terdapat variasi yang luas mengenai pengertian petani yang dibuat oleh satu negara dengan negara lain ataupun satu pemangku kepentingan dengan pemangku kepentingan yang lain. Sebagai contoh misalnya, definisi petani menurut Brasil berbeda dengan definisi petani menurut Amerika Serikat. Di Brazil, petani dianggap sebagai petani kecil jika: (1) mengolah lahan pertanian bersama dengan keluarganya (ia tidak mempekerjakan orang lain yang bukan keluarganya); (2) ukuran lahan lebih kecil dari 4 (empat) fiscal modules (1 modul setara dengan 5-110 ha, tergantung pada lokasinya); dan (3) hasil pertanian menjadi pendapatan utama bagi pemiliknya.

Pemerintah Amerika Serikat, tepatnya Departemen Pertanian Amerika Serikat, menggunakan istilah petani untuk semua skala, baik petani skala kecil, menengah maupun besar, namun setiap skala memiliki batasan yang jelas. Petani berskala kecil di Amerika Serikat merupakan pemilik usaha di bidang pertanian (agricultural business) di mana ia dan keluarganya merupakan pemilik terbesar dari usaha tersebut (he and his family own the majority of the business). Selain itu, petani berskala kecil juga dibatasi dari besarnya pendapatan. Petani disebut berskala kecil jika pendapatan per tahunnya berkisar 350.000 dolar Amerika Serikat. Petani dengan pendapatan per tahun 350.000 hingga 999.999 Dolar Amerika Serikat disebut petani berskala menengah, dan petani dengan pendapatan lebih dari 1 juta dolar Amerika Serikat disebut petani berskala besar (Hoppe and MacDonald, 2013).

Banyak sekali terminologi yang digunakan untuk memberikan istilah terhadap petani, khususnya petani berskala kecil termasuk istilah "smallholder", "peasant", "tenant", "sharecropper", "subsistence farmer", "family farmer" dan lain sebagainya. Istilah ini juga digunakan secara berbeda-beda oleh masingmasing negara dengan batasan tertentu. Namun demikian, Adams and Coward (1972) mendefinisikan petani kecil sebagai “... one who had very little access to political power, productive assets and/or income streams within society" Lebih jauh Adams and Coward menyatakan bahwa:

"they are complex interrelationships between animals, crops and farming families, involving small land holdings and minimum resources of labour and capital, from which small farmers may or may not be able to derive a regular and adequate supply of food or an acceptable income and standard of living" (Adam and Coward, 1972: 5).

Sementara Food and Agricultural Organization (FAO) memberikan definisi petani berskala kecil (small farmers) dalam cakupan yang luas. Petani berskala kecil adalah "... including the low-income producers of agricultural, livestock and aquatic products. 
They referred, in particular, to tenants, informal tenants such as share croppers, landless agricultural labourers and small owner-operators" (FAO, 1978: 72).

Walaupun banyak sekali definisi mengenai petani (berskala) kecil, namun menurut Ploeg, ada satu ciri yang memberikan persamaan diantara definisi-definisi tersebut yaitu:

“...self-controlled resource base, coproduction or interaction between humans and nature, cooperative relations that allow peasants to distance themselve from monetary relations and market exchange, an ongoing "struggle for autonomy" or "room from manuvers" that reduces dependency and aligns farming "with the interests and prospect of the...producers" (Jan Douwe van der Ploeg, 2009: 32).

Petani berskala kecil sangat menonjol sifat kerjasama satu dengan yang lainnya, mengusahakan pertanian dengan mengutamakan tenaga yang berasal dari keluarga mereka sendiri, dan menggunakan teknologi yang masih sangat sederhana serta biasanya hasil pertanian mereka untuk memenuhi kebutuhan konsumsi mereka sendiri. Selain itu, para petani yang masuk kategori ini belum terjangkau oleh program pembiayaan dari lembaga perbankan (Jan Douwe van der Ploeg, 2009: 32). Walaupun demikian, sebenarnya mereka inilah yang sesungguhnya secara riil menggerakkan pertanian dengan mengolah tanah, menanam benih, menyiram serta memanen hasil pertanian dengan tangan mereka sendiri (Syahyuti, 2013: 17).

\section{Evolusi Struktur Pertanian}

Sophia Murphy (2012) membagi tahapan evolusi struktur pertanian beserta peran petani ke dalam 4 (empat) periodesasi.

\section{a. Periode Tahun 1960-an hingga 1970 -} an

Periode ini dikenal sebagai periode "kembalinya industri pertanian". Tahun 1960 ditandai dengan banyaknya negara-negara Asia, Afrika dan Amerika Latin memerdekakan diri dari penjajahan kolonial. Konsentrasi kemiskinan pada periode tahun ini berada di kawasan Asia. Sementara sebagian besar negara Afrika tergolong negara yang sejahtera karena pendapatan mereka yang besar yang berasal dari ekspor bahan tambang mineral, logam dan pertanian; namun demikian, distribusi dari kesejahteraan belum menjadi perhatian yang utama. Negara-negara Eropa adalah pembeli utama komoditas yang berasal dari negara-negara Afrika guna memenuhi kebutuhan domestiknya.

Banyak negara berkembang yang mewarisi struktur dan kelembagaan pertanian zaman kolonial. Struktur pertanian zaman kolonial umumnyaa dibagi dua golongan besar. Golongan pertama adalah perkebunan besar, yang biasanya memproduksi tanaman untuk diekspor. Perkebunan besar dikuasai oleh pihak penjajah dan kaki tangannya (di beberapa negara, kepemilikan perkebunan besar oleh kaki tangan penjajah ini kemudian ada yang dinasionalisasi). Di negara-negara Amerika Latin, pemilik perkebunan besar biasanya adalah ekspatriat. Struktur kedua adalah petani, yang dalam hal ini adalah petani berskala kecil. Petani kecil ini merupakan mayoritas dari penduduk. Petani-petani ini adalah penggarap perkebunan-perkebunan besar peninggalan penjajah. Di beberapa kasus, petani-petani ini biasanya juga menaman tanaman untuk ekspor seperti kakao dan kopi di kebun milik mereka sendiri.

Pada periode ini, pemerintah pusat memiliki kontrol yang kuat atas produk pertanian dan pasar pertanian. Kebijakan pertanian secara umum meliputi penetapan harga pokok produk pangan, pengelolaan pasokan, subsidi dan pengendalian penjualan komoditas ke pasar domestik dan ekspor. Pemerintahan negara-negara secara umum berfokus pada penjualan produk pertanian ke pasar di perkotaan dan menjaga harga pangan tetap murah daripada pertanian yang bermanfaat. Dengan kata lain, produsen pertanian berskala kecil mensubsidi industrialisasi secara efektif.

Pemerintah bersama dengan koperasi dan serikat dagang berusaha untuk mendapatkan dukungan politik dan sosial dari pemilih di pedesaan melalui pemberian program-program dari kebijakan pertanian pemerintah 
pusat. Dilihat dari sudut pandang politik, penduduk desa dipandang sebagai masyarakat yang kurang berpendidikan, cenderung diam/ pasif dan miskin dibanding dengan penduduk di perkotaan. Oleh sebab itu, masyarakat miskin pedesaan menjadi obyek dari program-program pemerintah, khususnya di bidang pertanian. Pemerintah mengontrol kepemilikan lahan petani kecil, membatasi akses mereka ke input pertanian (bibit, pupuk, dsb), dan memutuskan di mana akan dibangun infrastruktur seperti irigasi, jalan, dan rel kereta api misalnya. Dalam beberapa kasus, negara melanjutkan sistem operasional perusahaan warisan zaman penjajahan dengan tujuan untuk mengatur (mendominasi) distribusi dan pemasaran komoditas pertanian (terutama komoditas yang ditujukan untuk ekspor seperti tembakau, bahan pangan seperti beras, gula dsb).

Pada masa ini, beberapa negara ada juga yang melaksanakan program reformasi Iahan (land reform) dan redistribusi kekayaan yang berkeadilan. Beberapa contohnya adalah revolusi yang dilaksanakan oleh Rusia dan China dengan sistem komunisnya; Tanzania yang sangat dipengaruhi oleh ideologi sosialisnya; serta reformasi lahan yang dilaksanakan di Kuba, Bolivia, Ethiopia dan Zambia. Dengan atau tanpa reformasi lahan, sebagian besar pemerintahan negara baru ini memiliki kontrol yang ketat pada sektor pertaniannya. Walaupun lahan didistribusikan kepada para petani, namun pemerintah tetap mendikte tanaman apa yang harus ditanam, berapa harga jual komoditas pertaniannya serta membatasi perpindahan penduduk kota ke desa.

\section{b. Periode Tahun 1980-an}

Akhir tahun 1970 hingga awal tahun 1980, krisis melanda pasar global dan nasional. Negara-negara berkembang tidak mampu lagi melanjutkan kebijakan mereka. Desakan untuk melakukan stabilitas harga telah membawa akibat antara lain: (a) menekan harga dari para produsen; (b) melemahnya investasi pada sektor produktivitas; dan (c) meningkatnya kebutuhan bahan pangan impor. Desakan yang kuat dari lembaga keuangan multilateral seperti International Monetary Fund (IMF) dan Bank Dunia (World Bank) untuk menderegulasikan sektor swasta menyebabkan tertekannya harga walaupun ekspansi produk meningkat (World Bank, 2007: 133).

Pengelolaan pasar komoditas global juga mengalami pergeseran pada periode ini. Harga komoditas pertanian menurun dan berakibat pada pengurangan pendapatan negara berkembang. Kelangkaan devisa juga diperburuk oleh devaluasi nilai mata uang negara-negara berkembang yang disebabkan karena penyesuaian struktural (structural adjustment) sehingga meskipun penjualan ekspor meningkat, tetap saja ketersediaan mata uang asing berkurang.

Beberapa negara yang meliberalisasi produk pertanian mereka membuat terobosan dalam rangka mengurangi kemiskinan di negaranya. Perpindahan penduduk dari desa ke kota (urbanisasi) menjadi pilihan alternatif yang diterapkan di banyak negara pada masa ini, termasuk Indonesia dan China. Gerakan urbanisasi ini mencerminkan keadaan di mana para petani yang sebagaian besar hidup di desa terpaksa berpindah profesi sebagai buruh di kota. Jikapun para petani tetap bertahan di desa dan mengerjakan lahannya, kehidupan mereka menurun. Dengan kata lain, pada periode ini, jumlah petani semakin berkurang karena kondisi ekonomi yang memburuk. Kesenjangan kesejahteraan antara penduduk kota dan desa juga semakin tajam. Dengan melihat pergeseran struktur pertanian pada tahun 1980-an ini, di mana petani menjadi kaum miskin (the poor), maka program-program pembangunan di desain untuk memindahkan mereka dari pekerjaan sebagai petani ke pekerjaan yang bersifat padat karya.

\section{c. Periode Tahun 1990-an}

Pada periode tahun 1990-an, kecenderungan dunia berfokus pada insiatif sektor swasta (private sector initiative). Sektor pertanian tradisional dianggap sudah tidak menguntungkan bagi sebagian kalangan kecuali dengan cara memperluas akses pasar untuk komoditas pertanian non-tradisional seperti holtikultura dan makanan laut. 
Pada tahun 1996, Food and Agricultural Organization (FAO) menjadi tuan rumah World Food Summit dan pada saat yang sama, isu ketahanan pangan mengemuka seiring dengan gencarnya isu perdagangan bebas yang disuarakan oleh World Trade Organization (WTO). Pada tahun 1994, Kanada, Amerika Serikat dan Meksiko menandatangani perjanjian perdagangan bebas NAFTA (North America Free Trade Agreement) yang menawarkan integrasi ekonomi yang lebih mendalam diantara ketiga negara ini. Pada tahun yang sama, General Agreement on Tarrifs and Trade (GATT) ditandatangani dan terbentuklah WTO dan mulai berlaku pada tanggal 1 Januari 1995. Salah satu perjanjian yang ada di dalamnya mengatur mengenai komoditas pertanian yang tertuang dalam Agreement on Agriculturel AoA. Ini artinya, sektor pertanian telah dibawa ke dalam sistem perdagangan multilateral yang sebelumnya sektor pertanian ini telah dikeluarkan dari sistem perdagangan melalui berbagai pengecualian (exceptions) dan keringanan (waivers).

Pada periode ini, terdapat pula serangkaian agenda konferensi yang diadakan oleh Perserikatan BangsaBangsa (PBB) yang sedikit berbeda dengan isu-isu sekitar pertanian, petani kecil dan peran pasar. Rangkaian konferensi tersebut adalah United Nations Conference on Environment and Development (atau yang biasa disebut "the Rio Summit") yang salah satunya menghasilkan bab tentang Sustainable Agriculture and Rural Development (Agenda 21, Chapter 14); Farmers as a Major Group (Agenda 21, Chapter 32). Selain itu juga the Framework Convention on Climate Change; the Convention on Biological Diversity; the World Summit on Social Development; the Beijing Women's Conference; dan juga United Nations Conferences on Human Rights, on Population, and on Housing. Ambang batas lingkungan untuk pembangunan, masalah-masalah kelaparan dan tentang teknologi baru seperti rekayasa genetika, semua dibahas di dalam konferensi ini. Organisasi masyarakat sipil dan gerakan sosial yang juga berperan aktif pada konferensi ini menegaskan bahwa liberalisasi perdagangan dan privatisasi bukan merupakan jawaban yang cukup memadai untuk menjawab tantangan pembanguan pertanian di masa yang akan datang.

d. Periode Tahun 2000-an (Periode Millenium Baru)

Secara umum, periode tahun 2000an adalah periode yang sulit bagi sektor pertanian, khususnya bagi petani kecil. Harga komoditas pangan di pasar global menurun, dan secara finansial, para petani berskala kecil banyak bergantung pada program pemerintah. Keadaan ini diperparah dengan adanya krisis pangan pada tahun 2007-2008. Menurut laporan Bank Dunia, jumlah penduduk kelaparan hingga tahun 2010 sekitar 850 juta jiwa atau setara dengan 15\% dari total populasi dunia (World Bank, 2010). Hal ini disebabkan pertumbuhan penduduk yang sangat tinggi yang tidak dibarengi dengan jumlah produksi pangan, karena kekeringan, erosi, serta dampak dari perubahan iklim. Konsensus internasional yang menyepakati bahwa perdagangan internasional dan investasi dapat digunakan sebagai sarana untuk mencapai pembangunan mulai dipertanyakan oleh beberapa kalangan (Ugarte and Murphy, 2009).

Globalisasi menjadi salah satu penyebab pergeseran struktur pasar komoditas pertanian. Reardon, seorang ahli ekonomi pertanian, dalam salah satu artikelnya yang dimuat di World Development Journal menyatakan bahwa transformasi struktur sistem pangan di negara-negara berkembang telah melampaui dan lebih signifikan dibandingkan dengan perkembangan perdagangan internasional. Investasi asing (foreign direct investment) di bidang pengolahan produk pertanian dan ritel produk olahan makanan (makanan cepat saji dan supermarket) mengalir deras ke negara-negara berkembang karena didorong meningkatnya permintaan konsumen perkotaan di negara berkembang atas produk olahan makanan. Transformasi ini sangat dipengaruhi oleh kebijakan eksternal dan internal suatu negara termasuk kebijakan penghapusan hambatan tarif, privatisasi, harmonisasi standar kualitas produk serta deregulasi arus investasi. 
Menjamurnya supermarket, makanan olahan, dan rantai makanan cepat saji di sebagian wilayah dunia telah mengubah bukan saja tentang bagaimana makanan itu diproses, disimpan dan didistribusikan; namun lebih dari itu, apa dan bagaimana tanaman itu tumbuh. Perubahan ini tentu saja berdampak pada petani sebagai ujung tombak rantai makanan khususnya dalam hal mengelola tenaga kerja. Sebagai contoh perkebunan anggur di Chile. Setiap perkebunan anggur di Chile mempekerjakan puluhan ribu orang agar dapat memenuhi tuntutan pasokan anggur, khususnya bagi pasar luar negeri (Berdegue, 2005: 181). Di Tanzania, setiap perkebunan bunga mempekerjakan 3.000 pekerja yang berasal dari luar Tanzania (sebagian besar dari mereka adalah perempuan) demi memenuhi kebutuhan bunga, baik di dalam negeri maupun di luar negeri (RiisGaard, 2009).

\section{Kedudukan Petani sebagai Aktor Penting dalam Produksi Pangan Global}

Mencermati evolusi struktur pertanian yang dikemukakan oleh Sophia Murphy di atas, keberadaan dan peran petani dalam setiap periodesasi mengalami transformasi. Setelah Perang Dunia kedua, bersamaan dengan munculnya isu ketahanan pangan, terjadi perubahan sistem perdagangan internasional dan struktur ekonomi. Perubahan ini pada akhirnya juga berdampak pada peran petani sebagai ujung tombak pertanian. Jika pada awal kemunculannya, isu ketahanan pangan hanya berkaitan dengan supply atau ketersediaan bahan pangan di dalam negeri, maka dengan perubahan sistem perdagangan internasional dan struktur ekonomi dunia sebagai dampak dari globalisasi, isu ketahanan pangan bertransformasi menjadi masalah distribusi dan akses pangan antar negara. Hal ini sejalan dengan pemikiran D. John Shawn bahwa:

"...from a situation of food shortages in the developing countries and the use of the so-called food "surpluses" of the developed countries, the focus switched to the importance of ensuring access by poor people to the food they needed trough increasing employment and purchasing power. At the same time, powerful forces entered the world food system, including the emergence of large multinational food corporations, which led to the increasing commercialization and control of the food chain, and population growth and urbanization, which resulted in a considerable expansion of world food trade" (D. John Shawn, 2007: 285).

Era globalisasi sekarang ini menjadikan petani, khususnya petani berskala kecil, dihadapkan pada kondisi yang sulit. Mereka harus bersaing dengan sistem distribusi pangan di pasar global yang dikendalikan oleh perusahaan-perusahaan multinasional. Di negara-negara berkembang, petani berskala kecil menghadapi tantangan yang cukup berat. Di China misalnya, struktur pertanian yang semula sepenuhnya dikendalikan oleh negara beralih menjadi dimungkinkannya produsen menyimpan dan menjual produksi mereka ke pasar swasta. Di negara-negara yang telah melakukan penyesuaian struktur (structural adjusment), para petaninya sangat menderita karena biaya produksi yang naik secara dramatis seiring dengan dihentikannya subsidi dari pemerintah sementara harga hasil panen rendah dan tidak stabil karena tergantung pada intervensi pemerintah dan meningkatnya tekanan impor.

Lebih lanjut, ketahanan pangan juga bergeser menjadi masalah akses terhadap bahan pangan. Para pakar menyatakan bahwa sebenarnya pasokan pangan di dunia ini melimpah selama empat puluh tahun terakhir, bahkan jumlahnya melebihi jumlah populasi dunia. Namun sayang, jumlah pasokan yang melimpah ini belum bisa mengatasi kelaparan yang terjadi di negara-negara di dunia, khususnya negara miskin. Dengan kata lain, kelaparan bukan disebabkan karena kemiskinan, namun lebih karena kurangnya akses terhadap tanah, kurangnya ketrampilan untuk barter, dan kurangnya akses kepada jaring pengaman.

Petani berskala kecil menghadapi kerugian yang sangat jelas dalam sistem global ini. Selain tidak memiliki modal yang besar dan organisasi yang menjadi tuntutan dari sistem global, para petani berskala kecil ini sangat sulit untuk memenuhi jumlah volume yang diminta oleh pasar, tuntutan kualitas serta akses mereka terhadap pasar tidak ada (World Bank, 2007). 


\section{Peran Petani dalam Sistem Perdagangan} Internasional

Peran petani dalam sistem perdagangan internasional dewasa ini disebut oleh Sophia Murphy sebagai "anakronisme", yaitu suatu keadaan di mana petani kecil berada pada kondisi yang sulit karena adanya perkembangan zaman (globalisasi), namun demikian pada waktu yang sama, petani kecil sebenarnya memiliki alternatif solusi untuk menghadapi kondisi tersebut. Keadaan ini digambarkan oleh Sophia Murphy sebagai bagan berikut.

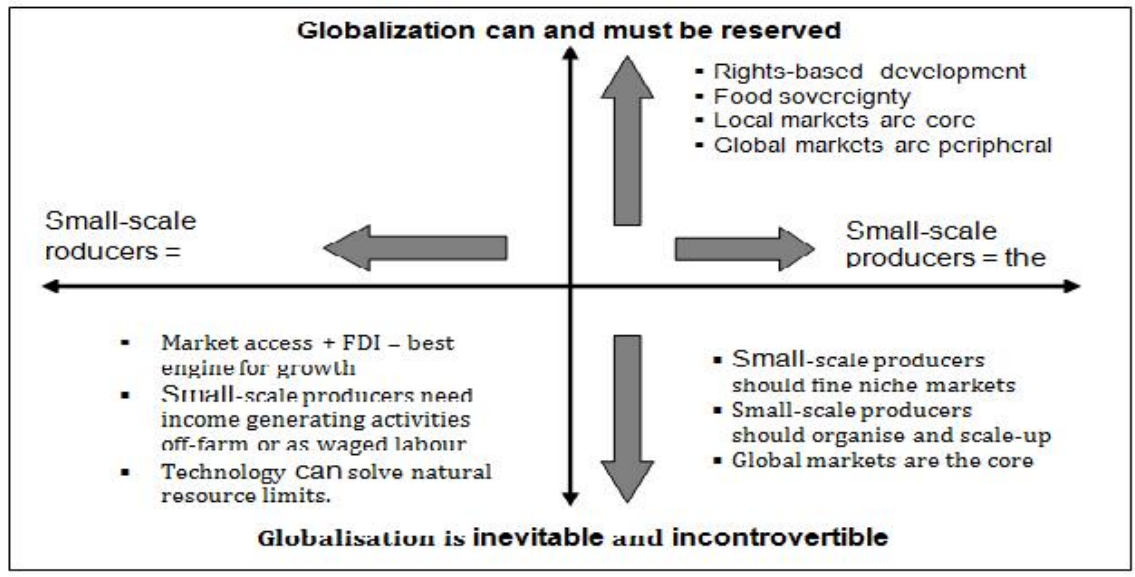

Di satu sisi, era globalisasi menjadikan petani berskala kecil berada pada kondisi yang sulit. Globalisasi mendorong adanya liberalisasi di segala bidang. Penurunan tarif menjadi kunci utamanya. Pembangunan suatu negara dibiayai dengan menggunakan investasi asing. Demikian pula di bidang pertanian. Guna meningkatkan pasokan pangan global di pasar dunia, maka menurut Collier (2008), cara yang paling realistis adalah dengan meniru model Brazil, yaitu melalui pendekatan "large, technologically sophisticated agro-companies" (P. Collier, 2008: ). Inti dari pendekatan ini terletak pada tersedianya padat modal di bidang pertanian yang akan menjadikan bidang ini menjadi lebih produktif. Cara-cara bertani yang dilakukan secara konservatif sudah ditinggalkan dan beralih ke industri pertanian. Investasi ditanamkan secara besar-besaran di bidang industri pertanian yang dimiliki oleh produsen besar serta di bidang diversifikasi non-pertanian sehingga juga dapat membuka lapangan pekerjaan dan menyerap tenaga kerja di luar bidang pertanian.

Namun di sisi lain, bagaimanapun juga, petani tetap dianggap sebagai mesin penggerak yang penting bagi pembangunan ekonomi. Penelitian yang dilakukan oleh International Food Policy Research Institute (IFPRI) menyatakan bahwa produksi pertanian berskala kecil yang dilakukan oleh para petani kecil menawarkan manfaat yang besar. Selain bekerja atas dasar pengetahuan dan keterampilan yang mereka miliki, para petani kecil ini dapat menjadi pengendali migrasi dari desa ke kota (urbanisasi), serta menjadi aktor yang penting dalam rangka ketahanan pangan untuk daerah yang tidak terjangkau oleh distribusi nasional (Peter Hazell and Xinshen Diao, 2005). Namun demikian, masalahnya terletak pada kemauan politik para pengambil kebijakan di bidang pertanian. Dukungan ini menjadi penting karena tanpa dukungan dari para pengambil kebijakan, maka peran petani kecil akan semakin terpinggirkan oleh arus globalisasi.

Lebih jauh, investasi di bidang pertanian perlu dilakukan oleh pemerintah jika menginginkan bidang pertanian dapat menjadi mesin penggerak pembangunan ekonomi. Pemerintah dalam hal ini harus memposisikan dirinya sebagai fasilitator bagi para petani kecil dalam menghadapi masa transisi dari ekonomi pertanian berbasis tradisional menuju ke pola ekonomi pertanian berbasis industri, di mana sektor pertanian akan semakin terdiversifikasi dalam rangka menghadapi perdagangan global yang semakin kompetitif dan dinamis (Valdes \& Foster, 2005).

\section{Simpulan}

Era globalisasi yang salah satunya ditandai dengan perubahan sistem perdagangan internasional menjadikan posisi petani menjadi semakin sulit. Penurunan tarif yang merupakan 
kunci dari liberalisasi dalam sistem perdagangan internasional yang dianut oleh sebagian besar bangsa-bangsa di dunia dewasa ini menjadikan petani kalah bersaing dengan sistem distribusi pangan yang dikendalikan oleh perusahaanperusahaan besar yang padat modal. Oleh sebab itu, diperlukan peran pemerintah dalam membantu mengatasi keadaan ini. Pemerintah diharapkan dapat menjadi fasilitator dalam menghadapi perubahan zaman yang terjadi sehingga petani dapat bangkit dari keterpurukannya.

\section{E. Saran}

Terkait dengan kedudukan dan peran petani yang semakin tidak berdaya dalam sistem perdagangan internasional, maka tiap negara seharusnya membuat sebuah model pendekatan yang tepat untuk menjembatani antara petani, pihak swasta dan pemerintah sehingga kedudukan dan peran petani di dalam sistem perdagangan internasional dapat semakin nyata.

\section{Daftar Pustaka}

Berdegué, J.A. 2005. The Future of Small Farms Proceedings of a Research Discussant Remarks. Workshop, Wye, U.K. June 26-29. London: IFPRI, ODI and Imperial College.

Collier, P. 2008. Reforming Agriculture. Comments on Martin Wolf's Economic Forum.

Crabtree, Benyamin F. 1995. Doing Qualitative. London: Sage Publication.

Hazell, P. and X. Diao. 2005. The Role of Agriculture and Small Farms in Economic Development, paper presented at The Future of Small Farms. Proceedings of a Research Workshop, Wye, U.K. June 26-29, 2005. London: IFPRI, ODI and Imperial College.

IAASTD. 2009. Agriculture at a Crossroads: The Synthesis Report. International Assessment of Agricultural Knowledge, Science and Technology for Development. Washington, DC: Island Pres

MacDonald, James M and Robert Hoppe. 2013. Farm Size and the Organization of US Crop Farming. Economic Reserach Report No. 152, August 2013.

Riisgaard, L. 2009. "Global Value Chains, Labor Organization and Private Social Standards: Lessons from East African Cut Flower Industries", World Development 37(2).

Shawn, D. John. 2007. World Food Security: A History Since 1945. New York: Palgrave Macmillan.

Valdes A., and W. Foster. 2005. Reflection on the Role of Agriculture in Pro-Poor Growth. Paper prepared for "the Future of Small Farms: Proceeding of a Research Workshop", June 26-29, 2005. London: IFPRI, ODI, and Imperial College.

Van Der Ploeg, Jan Douwe. 2009. The New Peasantries: Struggles for Autonomy and Sustainability in An Era of Empire and Globalization. London and Sterling: Earthscan.

Wiggins, S. 2009. Can the Smallholder Model Deliver Poverty Reduction and Food Security for a Rapidly Growing Population in Africa?. FAC Working Paper No. 8 Future Agricultures Consortium, Institute for Development Studies, UK.

World Bank. 2007. World Development Report 2008: Agriculture for Development. Washington DC: World Bank.

World Bank. 2010. Rising Global Interest in Farmland. Can It Yield Sustainable and Equitable Benefits?. Washington, DC: World Bank.

Artikel Jurnal:

Murphy S. 2009. Free Trade in Agriculture: A Bad Idea Whose Time is Done? Monthly Review, Vol. 61, Issue 3, July-August.

Syahyuti. 2013. "Pemahaman terhadap Petani Kecil sebagai Landasan Kebijakan Pembangunan Pertanian”. Forum Penelitian Agro Ekonomi, Vol. 31 No. 1, Juli 2013.

Internet:

FAO. 1978. The Small Farms Scenario. [www.fao.org/docrep/003/t0757e/T0757E02.htm, diakses tanggal 15 Maret 2014]. 